\title{
JPEB
}

Jurnal Penelitian Ekonomi dan Bisnis, 2 (1), 2017, Hal: 1 - 9

http://www.jpeb.dinus.ac.id

\section{ANALISIS TURNOVER INTENTION KARYAWAN GENERASI Y DI PROVINSI BANTEN SERTA FAKTOR YANG MEMPENGARUHINYA}

\author{
Nafiudin* \\ Program Studi Manajemen, Fakultas Ekonomi dan Bisins, Universitas Serang Raya \\ Jl. Raya Serang-CIlegon Km.5, Serang, Banten, Indonesia \\ *Corresponding Author: Nafiuddin08@gmail.com
}

Diterima : Januari 2017; Direvisi : Februari 2017; Dipublikasikan : Maret 2017

\begin{abstract}
This study aims to determine the factors that influence the turnover intention of generation $Y$ employees in Banten province, while the one that is the independent variable is work life balance and job satisfaction, while the terrestrial variable is turnover intention. The research method used in this study is a quantitative method with a descriptive associative approach and to answer the hypothesis in this study, then the test and $F$ test are used, while the population in this study is 135 and the research data is obtained by distributing questionnaires. And for processing data using the SPSS.20 program. Based on the results of the analysis using multiple linear regression, that simultaneously the work life balance variable, and job satisfaction affect the turnover intention of y generation employees in Banten province. While partially only job satisfaction variables that affect turnover intention. Therefore, it is better for companies in the province to pay attention to the job satisfaction of generation y employees.
\end{abstract}

Keywords: Work Life Balance; Job Satisfaction; Turn Over Intention

\section{ABSTRAK}

Penelitian ini bertujuan untuk mengetahui faktor-faktor yang mempengaruhi turnover intention karyawan generasi Y di provinsi Banten, adapun yang menjadi variabel bebas adalah work life balance dan kepuasan kerja sedangkan variabel teriktatnya adalah turnover intention. Metode penelitian yang digunakan dalam penelitian ini adalah metode kuantitatif dengan pendekatan asosiatif deskriptif dan untuk menjawab hipotesis dalam penelitian ini, maka digunakanlah uji $\mathrm{t}$ dan Uji F, adapun populasi dalam penelitian ini adalah sebanyak 135 dan data penelitian diperoleh dengan penyebaran kuesioner. Dan untuk pengolahan data menggunakan program SPSS.20. Berdasarkan hasil analisis dengan menggunakan regresi linier berganda, bahwa secara simultan variable work life balance, dan job satisfaction mempengaruhi turnover intention karyawan generasi y di provinsi banten. Sedangkan secara parsial hanya variable job satisfaction yang mempengaruhi turnover intention. Oleh karena itu sebaiknya perusahaan perusahaan yang berada di wilayah provinsi banten harus memperhatikan job satisfaction karyawan generasi y.

Kata Kunci: Work Life Balance; Kepuasan Kerja ; Turn Over Intention 


\section{PENDAHULUAN}

Sumber Daya Manusia menjadi peran penting untuk pencapaian keberhasilan organisasi atau perusahaan oleh karena itu manajemen perusahaan tidak hanya memperhatikan bahan mentah, alat-alat kerja, mesin-mesin produksi, uang dan lingkungan kerja akan tetapi manajemen perusahaan harus memperhatikan bagaimana mengelola sumber daya manusia. Ketidak pastian ekonomi dan politik akhir-akhir ini memberikan dampak besar pula terhadap ketidak pastian soal keuangan perusahaan dimana akan mempengaruhi karyawan terkait dengan masalah kepuasan kerja, keinginan untuk melapaskan diri, dan mengabaikan tugas mereka atau bahkan meninggalkan perusahaan. Dan para praktisi di bidang Human Resource Management mengkhawatirkan prilaku karyawan generasi Y, karyawan generasi Y adalah karyawan yang berusia dibawah 30 tahun(www.PortalHR.com: 2012), menurut laporan cultur shock karyawan Gen Y Di Inggris, hanya 57\% yang berniat untuk tetap bertahan di pekerjaan mereka saat ini, sementara di India $62 \%$ dan $75 \%$ di Timur Tengah.

Karyawan di Malaysia yang paling setia, 87\% karyawan menyatakan akan tetap bertahan di tempatnya bekerja . Dan berdasarkan survey yang dilakukan oleh Roberth Half terkait dengan Gen Y bahwa Generasi Y perlu mendapatkan perhatian yang serius, karena berdasarkan hasil survey bahwa 4 dari 10 (37\%) karyawan Gen Y akan pindah pekerjaan atau berhenti dari organisasi apabila kebutuhannya tidak terpenuhi www.PortalHR.com: 2016), Kinerja Organisasi atau perusahaan akan terganggu dengan perilaku karyawan Gen Y yang memiliki keinginan untuk berhenti dari perusahaan dan berpindah keperusahaan lainnya yang dianggap lebih memperhatikan kebutuhannya dan bukan sedikit dana yang telah dikeluarkan perusahaan untuk mendapatkan karyawan tersebut. Turnover akan berdampak negatif bagi organisasi karena menciptakan ketidakstabilan terhadap kondisi tenaga kerja, menurunnya produktifitas karyawan, suasana kerja yang tidak kondusif dan juga berdampak pada meningkatnya biaya sumber daya manusia Oleh karenanya perusahaan harus memperhatikan keseimbangan tuntutan pekerjaan dengan tuntutan kehidupan pribadi karyawan (work Life balance), dan Jobs Satisfaction. Karena perusahaan tidak hanya menaikan gaji saja untuk mempertahankan karyawan Gen Y. Work Life Balance merupakan perasaan karyawan untuk merasakan kebebasan dalam. memanfaatkan waktu kerja secara fleksibel guna menyeimbangkan antara tuntuntan pekerjaannya dengan tuntukan pribadi diluar pekerjaan seperti keluarga, hobi, seni, perjalanan, penelitian bukan hanya fokus pada pekerjaan, aktivitas - aktivitas ini mengarah kepada kepuasan kerja karyawan (Job Satisfaction) yang semuanya bermuara pada kinerja karyawan tersebut. Berdasarkan latar belakang di atas, maka perlu dilakukan sebuah penelitian guna mengetahui faktor-faktor apa saja yang dapat mempengaruhi turnover intention karyawan Generasi Y di Provinsi Banten mengingat bahwa berdasarkan data badan pusat statistik bahwa telah terjadi penurunan jumlah tenaga kerja di Provinsi Banten pada Agustus 2015 yaitu turun sebesar 29 ribu orang jika dibandingkan Agustus 2014( Berita Statistik , 2015).

Tujuan penelitian ini ingin menguji dan menganalisis bagaimana kondisi work life balance, Jobs satisfaction dan Turnover Intention karyawan Gen Y (Generasi Young) di Provinsi Banten, serta bagaimana pengaruh work life balance, jobs satisfaction terhadap turnover intention karyawan Gen Y di Provinsi Banten Baik secara parsial maupun simultan.

\section{TINJAUAN PUSTAKA Work Life Balance}

Malik et.al (2010: 27 ) menagatakan bahwa Work life balance adalah tentang bagaima karyawan menyeimbangkan tuntutan kerja dengan tuntutan yang lain seperti, keluarga, hobi dan kehidupan masyarakat. Untuk pengukuran work life balance menggunakan dua indikator 
pengukuran yaitu work life conflict dan life work conflict yang di adopsi dari Julie A.Waumsley,et al. (2010:3) dalam Nafiuddin (2015). Berdasarkan temuan dalam penelitian Malik (2010) bahwa turnover intention karyawan dapat dipengaruhi oleh work life balance. Micheal L. Shier, Dkk (2013). Kemampuan untuk menyeimbangkan tuntutan Pribadi dengan Pekerjaan secara siginifikan memprediksi kepuasan kerja dan Intention To Leave.

\section{Kepuasan Kerja}

Robbins (2008) dalam nafiudin (2015) bahwa kepuasan kerja sebagai sikap umum individu terhadap pekerjaannya. Dimensi kepuasan kerja yaitu meliputi pay, the work it self, promotion opportunities, supervision, cowokers dan work condition (Luthans, 2008) dalam nafiudin (2015), namun terdapat beberapa pakar yang menyatakan bahwa terdapat 5 dimensi utama kepuasan (Greenberg \& Baron, 2003:151; Hunt \& Osborn, 2005:143) yang terdiri dari pay, the work it self, promotion oppurtnities, supervision, dan Coworkers.

\section{Turnover Intention}

Turnover intention adalah keinginan seseorang untuk berhenti dari pekerjaannya dan mencari alternatif pekerjaan lain yang lebih baik dalam masa beberapa bulan yang akan datang. Wang et. All dalam Nugroho dan Anwar (2015:55) turnover intention merupakan kesadaran dalam diri seseorang untuk meninggalkan suatu organisasi yang ada saat ini, atau dengan kata lain bahwa turnover intention adalah tingkat dimana seorang karyawan memiliki kemungkinan untuk meninggalkan perusahaan Indikator yang dipergunakan untuk mengetahui intensi turnover dikembangkan dari hasil penelitian suhanto dalam nafiudin (2015) :

1. Pikiran untuk keluar

2. Keinginan untuk mencari lowongan pekerjaan lain

3. Adanya keinginan untuk meninggalkan organisasi dalam beberapa bulan Mendatang

\section{Kerangka Pemikiran Teoritis}

Adapun kerangka pemikiran pada penelitian ini adalah sebagai berikut

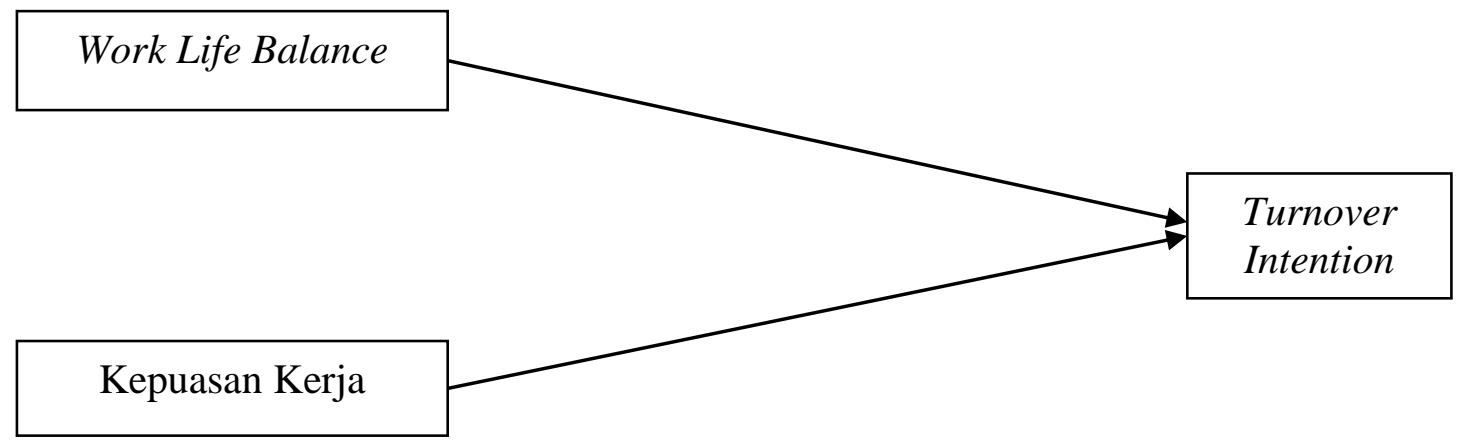

Gambar 1. Kerangka Pemikiran Teoritis

\section{METODE PENELITIAN}

Penelitian ini bersifat asosiatif dan deskriptif, karena penelitian ini memberikan gambaran terhadap fenomena dan juga menerangkan pengaruh, hubungan, menguji hipotesishipotesis membuat prediksi serta mendapatkan makna dan implikasi dari suatu masalah yang ingin dipecahkan. Penelitian deskriptif yang dilakukan terhadap variabel mandiri, tanpa 
membuat perbandingan atau menghubungkan dengan variabel lain yang bertujuan untuk memperoleh gambaran tentang varibel penelitian: work life balance, Job Satisfaction, dan turnover intention. Penelitian verifikatif dilakukan dengan menguji kebenaran hipotesis yang dilakukan melalui pengumpulan data dilapangan. Sifat penelitian verifikatif pada dasarnya ingin menguji kebenaran dari suatu hipotesis yang dilaksanakan melalui pengumpulan data.

Metode penelitian yang digunakan adalah descriptive survey dan explanatory survey karena penelitian ini menyoroti hubungan antara variabel work life balance, dan Job Satisfaction, sebagai (variabel independent) dengan variabel turnover intention sebagai veriabel yang dipengaruhi (dependent) dengan menguji hipotesis yang telah dirumuskan sebelumnya. Analisis data dalam penelitian ini menggunakan Analisis Regresi Berganda dengan bantuan program SPSS. Sedangkan pengujian hipotesis menggunakan Uji t dan Uji F.

\section{Populasi dan Sampel}

Populasi dalam penelitian ini adalah karyawan generasi Y yang bekerja di perusahaan berada di wilayah Provinsi Banten, adapun teknik pengambilan sampel dalam penelitian ini adalah convenience sampling yang termasuk kedalam non probability sampling yaitu teknik pengambilan sampel yang tidak memberi peluang atau kesempatan sama bagi setiap unsur atau anggota populasi untuk dipilih menjadi sampel. Pengambilan sampel dengan cara 5 jumlah parameter yang diestimasi. Paramater yang diestimasi dalam penelitian ini adalah 27 sehingga ukuran sampelnya adalah 5 dikalikan 27 yaitu 135.

\section{Metode Pengumpulan Data}

Untuk mengumpulkan data penelitian, kuesioner dipilih sebagai teknik pengumpulan data dalam penelitian ini. Kuesioner dipilih karena merupakan suatu mekanisme pengumpulan data yang efisien untuk mengetahui dengan tepat apa yang diperlukan dan bagaimana mengukur variabel penelitian (Sekaran, 2006). Untuk setiap pernyataan atau pertanyaan dalam kuesioner diberikan bobot atau skor dan pemberian skor dengan menggunakan skala Likert 5 poin adalah sebagai berikut:(1) Jawaban Sangat Setuju mendapat skor 5, (2) jawaban Setuju mendapat skor 4, (3) jawaban Netral mendapat skor 3 (4) jawaban Tidak Setuju mendapat skor 2,(5) Jawaban Sangat Tidak Setuju mendapat skor1.

\section{Tabel 1. Definisi Operasional Variabel}

\begin{tabular}{lll}
\hline Variabel & Definisi & Indikator \\
\hline Work Life Balance & Mc Shane (2010), work life & 1. Work Life Conflict. \\
& balance is the degree to & \\
& which a person minimizes & 2. Life Work Conflict \\
& conflict between work and & \\
& non work demand”. Dalam & \\
& muhamad Imran Malik. \\
& (2010)
\end{tabular}

Job satisfaction

\begin{tabular}{lrl}
$\begin{array}{l}\text { Adalah perasaan positif atau } \\
\text { negative individu terhadap }\end{array}$ & $\begin{array}{l}\text { Gaji yang lebih } \\
\text { baik }\end{array}$ \\
$\begin{array}{l}\text { pekerjaan mereka, sikap } \\
\text { umum atau respon }\end{array}$ & 2. Gaji yang cukup \\
emosional terhadap & $\begin{array}{l}\text { sesuai dengan } \\
\text { tanggung jawab } \\
\text { pekerjaanya. }\end{array}$ & 3. Kepuasan \\
(Schermerhorn, & tunjangan \\
Hunt Osborn (2005) & 4. Frekuensi promosi \\
& 5. Keyakinan pada \\
\hline
\end{tabular}


pekerjaan baik, maka diberikan promosi.

6. Kepuasan pada tingkat kemajuan bekerja

7. Kepuasan dukungan sesama rekan kerja

8. Kepuasan pada tanggung jawab rekan kerja.

9. Kepuasan pada hasil kerja rekan

10. Kepuasan dengan pengawas (Satisfaction with supervisor).

11. Kepuasan dengan pekerjaan itu sendiri (Satisfaction work it self)

12. Kepuasan pada dukungan atasan

13. Kepuasan pada motivasi kerja dari atasan

14. Kepuasan pada tingkat tanggung jawab

15. Kepuasan pada pekerjaan yang lain

16. Kepuasan pada keberhasilan kerja.

Turnover Intention
Niat untuk Pindah

(Turnover Intention) dalam penelitian ini didefinisikan sebagai keinginan seseorang 3 . untuk keluar dari perusahaan (Chen \& Francesco (2000) dalam Edi Suhanto(2010) ${ }^{1}$
1. Pikiran untuk keluar

2. Keinginan untuk mencari lowongan pekerjaan lain

. Adanya keinginan untuk meninggalkan organisasi dalam beberapa bulan Mendatang 


\section{HASIL DAN PEMBAHASAN}

\section{Persepsi Responden}

Tabel berikut ini merupakan tanggapan responden terhadap work Life Balance, kepuasan kerja dan turn over intention.

Tabel 2. Rekapitulasi Hasil Tanggapan Responden Terhadap Work Life Balance

\begin{tabular}{ccc}
\hline No & Indikator & Skor \\
\hline 1 & Work Life Conflict & 1994 \\
2 & Life Work Conflict & 1375 \\
& Jumlah & 3369 \\
\hline
\end{tabular}

Tabel 2 menggambarkan tanggapan responden mengenai work life balance. Berdasarkan hasil pengolahan yang disajikan pada tabel di atas, dapat dilihat bahwa skor total untuk work life balance adalah 3369. Jumlah skor tersebut dimasukkan ke dalam garis kontinum, yang pengukurannya ditentukan dengan cara :

Nilai Indeks Maksimum $\quad=5 \times 9 \times 135=6075$

Nilai Indeks Minimum $\quad=1 \times 9 \times 135=1215$

Jarak Interval $\quad=[$ nilai maksimum - nilai minimum $]: 5$

$=(6075-1215): 5$

$=972$

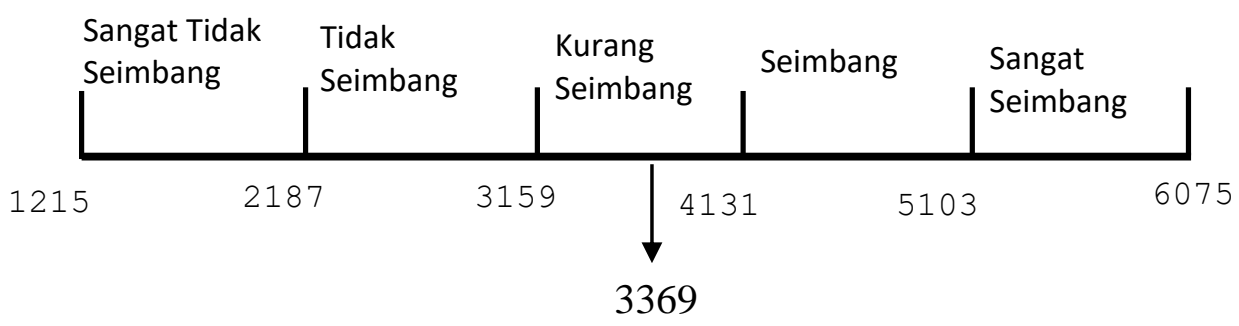

\section{Gambar 2. Garis Kontinum Work Life Balance}

Secara ideal, skor yang diharapkan untuk jawaban responden terhadap variable work life balance adalah 6075. Dari perhitungan dalam tabel menunjukkan nilai yang diperoleh 3369 atau 55,4\% dari skor ideal yaitu 6075 . Dengan demikian work life balance berada pada kurang seimbang.

Malik, et al ( 2010) dalam penelitiannya menyatakan bahwa work life balnce memiliki hubungan yang kuat dalam mengurangi tingkat keinginan untuk keluar dari perusahaan atau pindah pekerjaan. Dalam penelitian ini bahwa secara bersama-sama work life balance dan kepuasan kerja dapat mempengaruhi keinginan karyawan untuk pindah perusahaan atau pindah pekerjaan. 
Nafiudin : Analisis Turnover Intention Karyawan Generasi Y Di Provinsi Banten Serta Faktor Yang Mempengaruhinya

Tabel 3. Rekapitulasi Hasil Tanggapan Responden Terhadap Kepuasan Kerja

\begin{tabular}{clc}
\hline No & \multicolumn{1}{c}{ Dimensi } & Skor \\
\hline 1 & Kepuasan Gaji & 1387 \\
2 & Kepuasan dengan Promosi & 1462 \\
3 & Kepuasan Dengan Rekan Kerja & 1503 \\
4 & Kepuasan dengan Penyelia & 1503 \\
5 & Kepuasan dengan Pekerjaan Itu Sendiri & 925 \\
& Jumlah & 6780 \\
\hline
\end{tabular}

Tabel 3 menggambarkan tanggapan responden mengenai kepuasan kerja. Berdasarkan hasil pengolahan yang disajikan pada tabel di atas, dapat dilihat bahwa skor total untuk kepuasan kerja (job satisfaction) adalah 6780. Jumlah skor tersebut dimasukkan ke dalam garis kontinum, yang pengukurannya ditentukan dengan cara :

Nilai Indeks Maksimum $=5 \times 13 \times 135=8775$

Nilai Indeks Minimum $\quad=1 \times 13 \times 135=1755$

Jarak Interval $\quad=$ [nilai maksimum - nilai minimum $]: 5$

$=(8775-1755): 5$

$=1404$

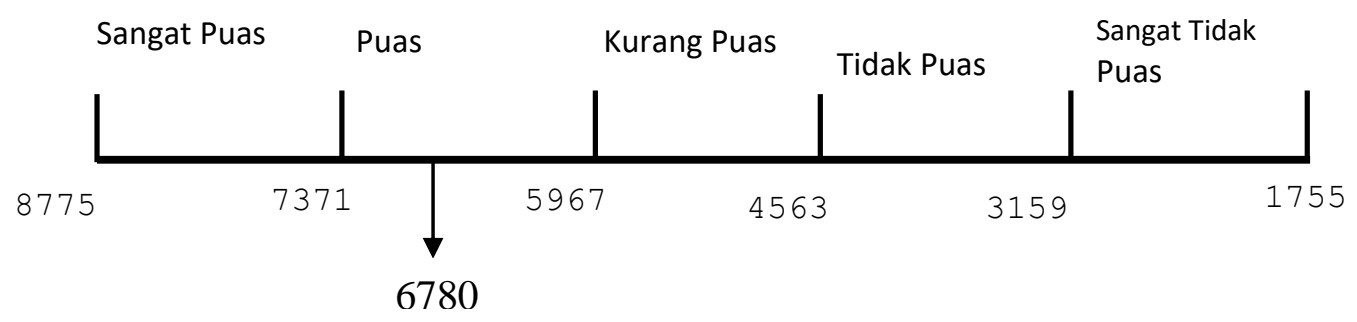

Gambar 3. Garis Kontinum Kepuasan Kerja

Secara ideal, skor yang diharapkan untuk jawaban responden terhadap variable Kepuasan Kerja adalah 8775 Dari perhitungan dalam tabel menunjukkan nilai yang diperoleh 6780 atau 77,2 \% dari skor ideal yaitu 8775. Dengan demikian Kepuasan Kerja berada pada kategori Puas. Walaupun demikian akan tetapi harapannya adalah kondisi kepuasan kerja karyawan generasi y di provinsi Banten pada tingkat sangat puas. Karena kepuasan kerja mempunyai pengaruh terhadap keinginan karyawan untuk tetap bertahan dalam sebuah perusahaan, seperti apa yang sudah dilakukan oleh Nugroho dan Anwar Santoso (2015) dalam penelitiannya bahwa kepuasan kerja berpengaruh terhadap turnover intention karyawan.

Tabel 4. Rekapitulasi Hasil Tanggapan Responden Terhadap Turnover Intention

\begin{tabular}{clc}
\hline No & \multicolumn{1}{c}{ Indikator } & Skor \\
\hline 1 & Sering Berfikir untuk Berhenti & 416 \\
2 & Aktif mencari pekerjaan di tempat lain & 406 \\
3 & Beberapa bulan mendatang berencana meninggalkan perusahaan & 365 \\
& \multicolumn{1}{c}{ Jumlah } & 1187 \\
\hline
\end{tabular}

Tabel di atas menggambarkan tanggapan responden mengenai turnover intention. Berdasarkan hasil pengolahan yang disajikan pada tabel di atas, dapat dilihat bahwa skor total 
untuk turnover intention adalah 1131. Jumlah skor tersebut dimasukkan ke dalam garis kontinum, yang pengukurannya ditentukan dengan cara :

Nilai Indeks Maksimum $\quad=5 \times 3 \times 135=2025$

Nilai Indeks Minimum $\quad=1 \times 3 \times 135=492$

Jarak Interval $\quad=$ [nilai maksimum - nilai minimum $]: 5$

$=(2025-492): 5$

$=306.6$

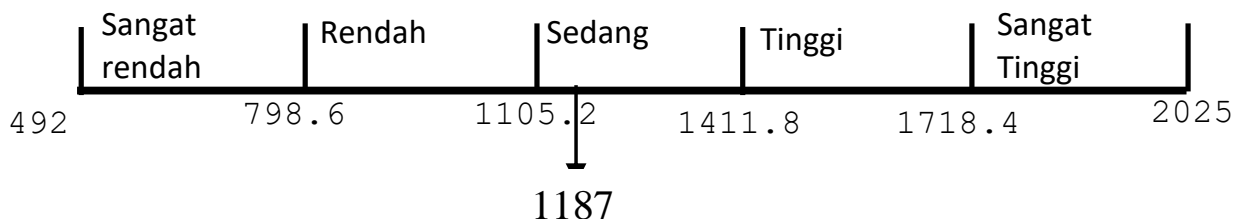

Gambar 4. Garis Kontinum Turnover Intention

Secara ideal, skor yang diharapkan untuk jawaban responden terhadap variable Turnover intention adalah 2460. Dari perhitungan dalam tabel menunjukkan nilai yang diperoleh 1187 atau $58.6 \%$ dari skor ideal yaitu 2025 Dengan demikian Turnover intention berada pada kategori Sedang.

\section{Analisis Regresi Berganda}

Tabel 5. Hasil Regresi

\begin{tabular}{cllrc}
\hline Model & \multicolumn{1}{c}{ Dependen } & \multicolumn{1}{c}{ Independen } & Beta & Sign \\
\hline 1 & Turnover Intention & work life balance & 0.071 & 0.386 \\
& & & -0.381 & 0.000 \\
& & & & \\
& & & & 0.000 \\
\hline
\end{tabular}

. Berdasarkan hasil analisis regresi pada table 5, nilai signifikansi work life balance adalah sebesar 0.386 di atas 0,05 dengan signifikansi lebih besar dari 0,05, maka hipotesis pertama work life balance tidak berpengaruh signifikan terhadap turnover intention karyawan generasi y. akan tetapi masih pada tingkat kepercayaan 90\% bahwa work life balance memiliki pengaruh yang signifikan terhadap turnover intention.

Sedangkan untuk variabel kepuasan kerja memiliki nilai signifikansi sebesar 0,000 lebih kecil dari 0,05, oleh karena itu dapat disimpulkan bahwa kepuasan kerja (Job Satisfaction) berpengaruh signifikan terhadap turnover intention karyawan generasi y. Hasil penelitian ini membuktikan bahwa jika karyawan memiliki kepuasan kerja yang sangat rendah akan mempengaruhi tingkat keinginan untuk pindah pekerjaan atau berhenti dari pekerjaan dan hasil penelitian ini sejalan dengan penelitian yang sebelumnya seperti hasil penelitian yang dilakukan oleh Nugroho dan Santoso (2015). Mi Yu and Kyung Ja Kang, (2016) juga menyatakan sama bahwa untuk mengurangi tingkat keinginan untuk meninggalkan perusahaan adalah memberikan kepuasan kerja.

\section{SIMPULAN}

Adapun kesimpulan dalam penelitian ini adalah sebagai berikut:bahwa work life balance tidak berpengaruh terhadap turnover intention karyawan generasi y di provinsi Banten, sedangkan kepuasan kerja berpengaruh signifikan.. Berdasarkan hasil rekapitulasi 
tanggapan responden terkait dengan work life balance dapat disimpukkan bahwa work life balance karyawan generasi y di provinsi Banten dalam kategori kurang seimbang, sedanggkan untuk kepuasan kerja dalam kategori puas dan tingkat turnover intention dalam kategori sedang.

Sedangkan Untuk mereduksi keinginan karyawan generasi Y yang ada di Provinsi Banten untuk berhenti dari pekerjaan atau pindah pekerjaan adalah memberikan kepuasan kerja karena berdasarkan hasil penelitian faktor ini lah yang mempengaruhi dibandingkan dengan faktor work life balance. Walaupun demikian faktor kepuasan kerja dan work life balance juga sudah seyogyanya menjadi perhatian khusus bagi para praktisi manajemen sumber daya manusia karena dua hal tersebut bisa menjadi faktor pertimbangan ketika perusahaan berkeinginan untuk mempertahankan karyawan generasi y di provinsi Banten.

\section{DAFTAR PUSTAKA}

A, Waumsley Julie. 2010. What about us? Measuring the work life balance of people who do not have children. United Kingdom: The University Of Kent

Edi, Suhanto. 2009. Pengaruh Stres Kerja Dan Iklim Organisasi Terhadap Turnover Intention Dengan Kepuasan Kerja Sebagai Variabel Intervening (Studi Di Bank Internasional Indonesia). Semarang: Universitas Diponegoro

Greenberg, Jerald. Baron, Robert, 2003. Behavior In Organization, Understanding And Managing Human Side Of Work. $8^{\text {th }}$ ed. New Jersey: Prentice Hall

Imran, Malik. Muhammad Solomon. Fernando,Gomez. Mehboob Ahmad, Muhammad Iqbal Saif. 2010. Examining The Relationship Ofwork Life Balance, Job Satisfaction And Turnover In Pakistan. Pakistan: Foundation University Islamabad.

Laurel, Cnall. 2010. Flexible Work Arrangements, Job Satisfaction, and Turnover Intentions:The Mediating Role of Work-to-Family Enrichment. The Journal of Psychology.144 (1): 61-81

Micheal, Shier. 2013. Social Workers and Satisfaction with Child Welfare Work: Aspects of Work, Profession, and Personal Life that Contribute toTurnover. Journal Inside

Mi, Yu. Kyung Ja Kang. 2016. Factors Affecting Turnover Intention for New Graduate Nurses in Three Transition Periods for Job and Work Environment Satisfaction The Journal of Continuing Education in Nursing.

Nafiudin.2015. Pengaruh work Life Balance dan Kepuasan Kerja Terhadap Turnover Intention Karyawan pada PT Bank Agroniaga Tbk. Cabang Bandung. Jurnal sains Manajemen 1 (1).

Nazim, Ali. 2010. Factors Affecting Overall Job Satisfaction and Turnover Intention. Pakistan: Qurtuba University of Science \& IT.

Nugroho, Edy, Anwar Santoso.2015. Pengaruh Kepuasan Kerja dan Stress Kerja terhadap turnover Intention ( Studi Kasus Pada PT Istana Kebayoran Raya Motor Cabang pondok Indah). Jurnal Sains Manajemen. 1 (2).

Osborn, Hunt Schermerhorn. 2005. Organizational Behavior. 9 ed. John Wiley \& Sons, Inc.

Sekaran, Uma. 2006. Research Methods for Business. Jakarta: Penerbit Salemba Empat.

Yu, Sun Zhenni Luo. Engqian Fang. 2013. Factors Influencing the Turnover Intention of Chinese Community Health Service Workers Based on the Investigation Results of Five Provinces. J Community Health.38:1058-1066 